\title{
Long-term growth and productivity projections in advanced countries
}

\author{
Gilbert Cette, ${ }^{1}$ Rémy Lecat ${ }^{2} \&$ Carole Ly-Marin ${ }^{1}$
}

\author{
Working Paper \#617
}

\author{
December 2016
}

\begin{abstract}
In this period of uncertainty about future economic growth, we have developed a growth projection tool for 13 advanced countries and the euro area at the 2100 horizon. This high uncertainty is reflected in the debate on the possibility of a 'secular stagnation'. Our projection tool allows for the modelling of technology shocks, for different speeds of regulation and education convergence, with endogenous capital growth and TFP convergence processes. We illustrate the benefits of this tool through four growth scenarios, crossing the cases of a new technology shock or secular stagnation with those of regulation and education convergence or of absence of reforms. Over the 2015-2100 period, the secular stagnation scenario assumes yearly TFP growth of $0.6 \%$ in the US, leading to a $1.5 \%$ GDP growth trend. The technology shock scenario assumes that the third technological revolution will, in the US, provide similar TFP gains to electricity during the second industrial revolution, leading to a $1.4 \%$ TFP trend, to which we add a TFP growth wave peaking in 2040, and thus to an average GDP growth rate of $3 \%$ in the US. In non-US countries, GDP growth will depend on the implementation of regulation reforms, the increase in education and on the distance to the country-specific convergence target. Over the period 2015-2060, for the euro area, Japan and the United Kingdom, benefits from regulation and education convergence would amount to a 0.1 to 0.4 pp yearly growth rate depending on the initial degree of rigidity and of the TFP distance to the US.
\end{abstract}

Keywords: Growth, productivity, long-term projections, structural reforms, innovation, education JEL codes: 011, 033, 043, 047, 057.

\footnotetext{
${ }^{1}$ Banque de France and AMSE

${ }^{2}$ Banque de France
}

Working Papers reflect the opinions of the authors and do not necessarily express the views of the Banque de France. This document is available on the Banque de France Website.

Les Documents de travail reflètent les idées personnelles de leurs auteurs et n'expriment pas nécessairement la position de la Banque de France. Ce document est disponible sur le site internet de la Banque de France. 


\section{NON-TECHNICAL SUMMARY ${ }^{3}$}

In developed countries, future long-term growth topics have received greater attention over the last few years in the context of the Great Recession and of lower average growth than at any time since WWII. The current situation thus logically raises the question: Are developed countries going to suffer from a long period of low growth or are they once again going to benefit from a wave of higher growth associated with a new technology revolution? To use an expression coined by Hansen (1939), and applied to the current situation by Summers $(2014,2015)$ and Eichengreen $(2015)$ among others, are we facing the risk of 'secular stagnation'? Such a 'secular stagnation' may have both demand and supply side origins. The prospect of a long period of low growth is alarming, not only because it would reduce improvements in purchasing power and living standards, but also because it would make it harder to face what Gordon $(2012,2013)$ calls the 'six headwinds'.

This study deals with future long-term growth and is associated with a user-friendly software tool that allows the construction of different scenarios. ${ }^{4}$ The originality of our study is twofold. First, it is a supply side approach that attempts to infer productivity growth from technological innovations in the US, to which other countries converge as it is considered to remain the technological frontier throughout the period; education and regulatory reforms being the main drivers of this productivity catch-up process. Second, the analysis is supplemented by a user-friendly software that enables the construction of growth scenarios by modeling technology shocks at the frontier (the US) and the catch-up process of other countries according to education and regulation hypotheses. As it is a supply side approach that gives a large role to technology waves, the horizon is very long and scenarios can be built starting from the current period to 2100 , with an annual step. We consider 13 developed countries and the euro area, which together represent more than half of the current world GDP. ${ }^{5}$ Specific scenarios can be developed for each of them.

Users operating the study's associated software can build diverse productivity scenarios for the US, the technological frontier. Given exogenous employment growth and an endogenization of capital growth, US GDP growth is determined by the total factor productivity (TFP) scenario. For other countries, productivity scenarios depend on the US's, but also on the country's specific catch-up process, itself subject to the hypotheses concerning education and regulation. As for the US, with the same exogenous employment growth and endogenization of capital growth, non-US country GDP growth scenarios are associated with these productivity scenarios.

The software presented in the paper is used to build different scenarios illustrating growth uncertainties at a very long horizon. These scenarios are deliberately extremely contrasted, and show how wide the range of possible future growth is for the developed countries. In the low-growth scenario, improvements in purchasing power and living standards would be very small, making it challenging to face the 'headwinds' described by Gordon $(2012,2013)$. Social and political stability could be seriously threatened in such a low growth scenario. By contrast, in the high-growth scenario, gains in purchasing power and living standards would be large, and Gordon's 'headwinds' would be easily overcome. Over the 2015-2100 period, the secular stagnation scenario assumes yearly TFP growth of $0.6 \%$ in the US, leading to a $1.5 \%$ GDP growth trend. The technology shock scenario (cf. graph below) assumes that the third technological revolution will, in the US, provide similar TFP gains to electricity during the second industrial revolution, leading to a $1.4 \%$ TFP trend, to which we add a TFP growth wave peaking in 2040 , and thus to an average GDP growth rate of $3 \%$. In

\footnotetext{
3 We warmly thank Roxanne Tabouret for her precious research assistance.

4 Available at www.longtermproductivity.com

5 These countries are the G7 (the United States, Japan, Germany, France, the United Kingdom, Italy and Canada), four other euro area countries (Spain, the Netherlands, Belgium and Finland) and two other advanced countries (Australia and Sweden).
} 
non-US countries, GDP growth will depend on the implementation of regulation reforms, the increase in education and on the distance to the country-specific convergence target, namely the US, as well. Over the period 2015-2060, for the euro area, Japan and the United Kingdom, benefits from regulation and education convergence would amount to a 0.1 to $0.4 \mathrm{pp}$ yearly growth rate depending on the initial degree both of rigidity and the TFP distance to the US.

There is no consensus in the literature on the future of growth drivers and, for this reason, it seems difficult to attribute probabilities to these different scenarios. We assume that the future growth of developed countries will probably settle between the extreme scenarios described in the paper, but the literature is not yet very conclusive in helping identify exactly where. But the software can be used to build more precise scenarios for those who have a specific opinion on what may happen regarding growth drivers over the next decades.

This software is of course based on a set of hypotheses and simplifications. For example, It does not yet allow for the introduction of different demographic scenarios nor for explicit account to be taken of the issue of environmentally sustainable growth. It is the first step in a long research program, the next two steps being the inclusion of both of these aspects in our basic framework. Bearing this in mind, it is still a practical tool that enables us to coherently represent different possible growth paths, and to characterize the associated issues in developed countries.

Illustrative graph of the "Technology shock" scenario

Average yearly GDP growth and contributions - In \% and percentage points

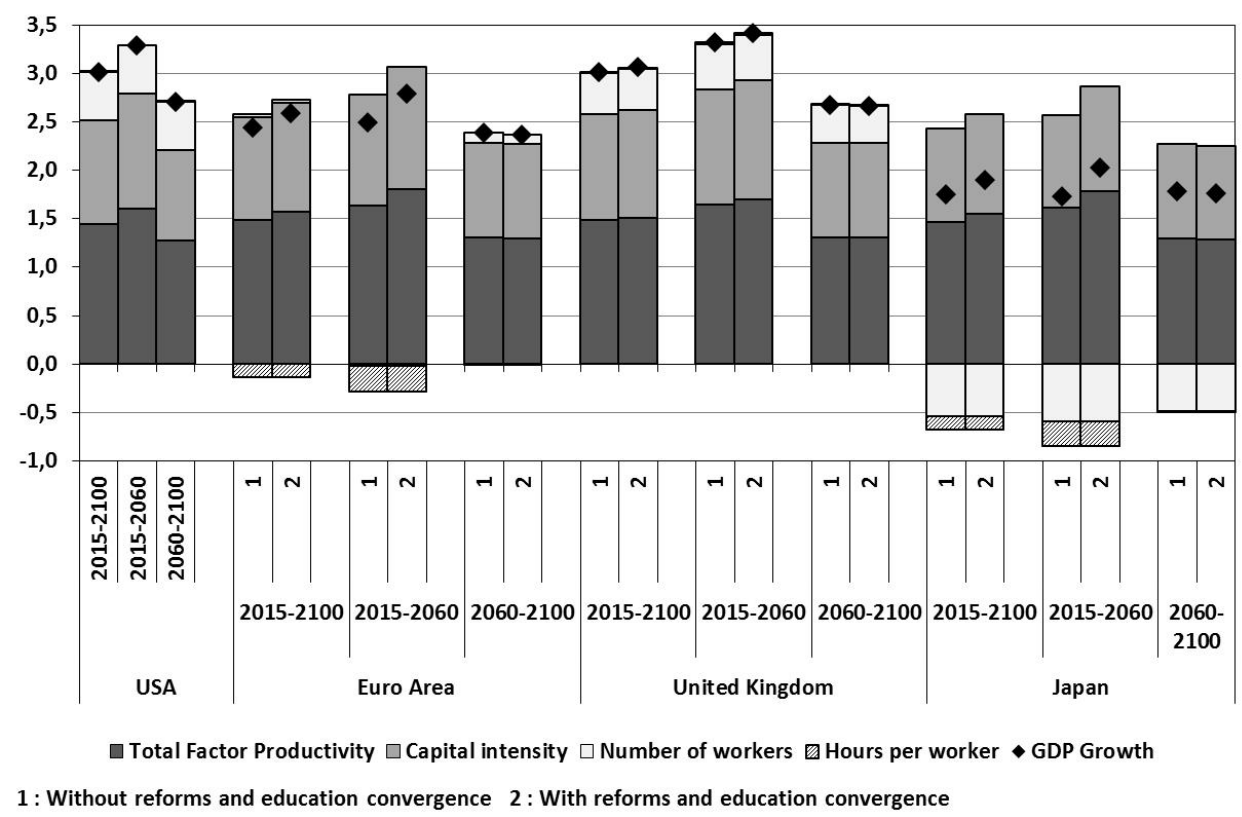

Source: Authors' computations.

Notes: this chart presents average yearly GDP growth under the technology shock hypothesis, with (2) and without (1) reforms (convergence of regulation and average years of education in the working-age population to the US level). GDP growth is decomposed into the contribution of TFP, capital intensity, the number of employees (labor) and hours worked per employee (hours). 


\section{Résumé : PROJeCtIONS de CROISSANCE ET DE PRODUCTIVITÉ À LONG TERME}

Dans cette période de forte incertitude sur les perspectives de croissance économique, nous avons développé un outil de prévision à l'horizon de 2100 pour 13 pays avancés et la zone euro. Cette forte incertitude est reflétée par le débat sur la possibilité d'une "stagnation séculaire ". Ce débat a été nourri par le fait que le choc des technologies de l'information et de la communication (TIC) a été bref et que la croissance du PIB et de la productivité a été faible dans les pays avancés. Notre outil de projection permet de modéliser les chocs technologiques, pour différents rythmes de convergence des réglementations et du niveau d'éducation, avec une croissance du stock de capital et une convergence de la PGF endogènes. Nous illustrons l'intérêt de cet outil par quatre scénarios de croissance, en croisant les cas d'un nouveau choc technologique ou d'une stagnation séculaire avec ceux de convergence des régulations et du niveau d'éducation ou d'absence de réformes. Sur la période 2015-2100, le scénario de stagnation séculaire suppose une croissance de la PGF de 0,6\% aux États-Unis, conduisant à une croissance tendancielle du PIB de 1,5\%. Le scénario de choc technologique suppose qu'une troisième révolution industrielle conduira aux mêmes gains de PGF que l'électricité pendant la $2^{\text {ème }}$ révolution industrielle, entraînant une tendance de PGF de 1,4\%, correspondant à une vague de croissance de la PGF atteignant son pic en 2040. Ceci permet de déboucher sur une croissance annuelle moyenne du PIB de 3\% aux États-Unis. Hors les États-Unis, la croissance du PIB dépendra de la mise en œuvre de réformes structurelles, de l'augmentation du niveau d'éducation et de la distance à l'objectif de convergence, spécifique à chaque pays. Sur la période 2015-2060, pour la zone euro, le Japon et le Royaume-Uni, les bénéfices de la convergence des réglementations et des niveaux d'éducation atteindraient 0,1 à 0,4 point de croissance par an, selon le degré initial de rigidité et de l'écart de niveau de PGF avec les États-Unis.

Mots-clés : croissance, productivité, projections de long terme, réformes structurelles, innovation, éducation. 


\section{Introduction}

In developed countries, future long-term growth topics have received growing attention over the last few years in the context of the Great Recession and of lower average growth than at any time since WWII. The current situation thus logically raises the question: are developed countries going to suffer from a long period of low growth or are they once again going to benefit from a wave of higher growth associated with a new technology revolution? The prospect of a long period of low growth is alarming, not only because it would reduce purchasing power and improvements in living standards, but also because it would make it harder to face what Gordon $(2012,2013)$ names the 'six headwinds'. These 'six headwinds', which are already in action and could potentially play a larger role in the future, are: i) a reversal of the demographic dividend; ii) a plateau in educational attainment; iii) rising income and wealth inequalities; iv) globalization; v) energy and environmental risks; and vi) the twin household and government deficits. These 'six headwinds' could contribute to low growth and in turn, low growth would make them more damaging.

To use an expression coined by Hansen (1939), and applied to the current situation by Summers $(2014,2015)$ and Eichengreen (2015) among others, are we facing the risk of 'secular stagnation'? ${ }^{1}$ Such a 'secular stagnation' appears to have both demand and supply side origins.

Concerning demand, it appears to be the consequence of a structural disequilibrium between saving and investment. A large saving glut could have numerous causes: for example, a growing share of emerging countries (such as China) with high saving rates in the world economy, a growing share of large companies with high saving rates in developed countries (such as the GAFA: Google, Amazon, Facebook and Apple), the increase of income inequalities as the saving rate increases with income, etc. Other causes may be, among others, declining investment opportunities or decreasing investment prices. From this disequilibrium, the natural real interest rate could turn negative and in the context of low inflation and of the zero lower bound limit to interest rates, monetary policy would not be able to lower the saving rate. With regard to the supply side, productivity has slowed down in all advanced countries since the beginning of the $2000 \mathrm{~s}$, before the current crisis. ${ }^{2}$ This fact is now well documented by several recent studies (see for example for the US, Gordon, 2012, 2013, 2014, 2015, or Byrne, Oliner and Sichel, 2013, and for all advanced countries, Crafts and O'Rourke, 2013, or Bergeaud, Cette and Lecat, 2016a). These countries already suffered from productivity slowdowns at the end of the 1960s, during the 1970s, towards the end of the 1980s, and during the 1990s, except for the US where, from the mid-1990s, we observe an acceleration due to faster improvement in information and communication technologies (ICT hereafter) productive performances (Jorgenson, 2001, was the first of numerous papers to stress this last point). Productivity growth is now very low, even close to nil in some countries, and, for some authors such as Gordon (2012, 2013, 2014, 2015), this situation could be the future of long-term productivity.

1 The causes of secular stagnation risk were for Hansen (1939) a demographic slowdown but also a disequilibrium between saving and investment.

2 Productivity has accelerated in Spain since 2008, the beginning of the current crisis, for very specific reasons (see Bergeaud, Cette and Lecat, 2016a). 
This study deals with the topic of future long-term growth, and is associated with a userfriendly software tool that allows the construction of different scenarios. ${ }^{3}$ Previous studies have suggested future long-term scenarios associated with different types of issues. Duval and Maisonneuve (2009) proposed a long-term scenario at the 2060 horizon for the world divided into ten areas. The main questions treated in this study were the crucial role of education and the growth impact of reforms in non-US areas. Fouré, Benassy-Quéré and Fontagné (2013) developed scenarios for 147 countries at the 2050 horizon. Key issues included the role of energy, female participation and the international circulation of savings financing capital growth.

The originality of our study is twofold. First, it is a supply side approach that attempts to infer productivity growth from technological innovations in the US, to which other countries converge as it is considered to be the technological frontier; education and regulation being the main drivers of this productivity catch-up process. Second, as mentioned previously, the analysis is supplemented by a user-friendly software that enables the construction of different scenarios related to productivity growth from technology shocks at the frontier (the US) and the catch-up process of other countries from education and regulation hypotheses. As it is a supply side approach that gives a large role to technology waves, the horizon is very long and scenarios can be built with an annual step from the current period to 2100 , the end of the century. Mainly using the Bergeaud, Cette and Lecat (2016a) database, ${ }^{4}$ we consider 13 developed countries and the euro area, which together represent more than half of current world GDP. Specific scenarios can be developed for each of them. ${ }^{5}$

Concerning possible settings, users operating the study's associated software can build diverse productivity scenarios for the US, the technological frontier. Given exogenous employment growth and an endogenization of capital growth, US GDP growth is determined by the total factor productivity (TFP) scenario. For other countries, productivity scenarios depend on the US's, but also on the country's specific catch-up process, itself subject to hypotheses concerning education and regulation. As for the US, with the same exogenous employment growth and endogenization of capital growth, non-US country GDP growth scenarios are associated with these productivity ones.

The remainder of the paper is organized as follow: Section 2 presents the model and Section 3 the data. Sections 4 and 5 detail the endogenization of capital and the productivity catch-up process respectively. Section 6 comments some scenarios built with the software associated with the model. Section 7 concludes.

\section{The model}

The model is a supply one based, at the national level, on the following usual two-factor (capital and labor) Cobb-Douglas production function, with constant returns to scale:

$$
Q_{i, t}=T F P_{i, t} \cdot K_{i, t-1}^{\alpha} \cdot\left(N_{i, t} \cdot H_{i, t}\right)^{1-\alpha}
$$

\footnotetext{
Available at www.longtermproductivity.com

This database can be accessed at http://www.longtermproductivity.com.

These countries are the G7 (the United States, Japan, Germany, France, the United Kingdom, Italy and Canada), four other euro area countries (Spain, the Netherlands, Belgium and Finland) and two other advanced countries (Australia and Sweden).
} 
Where $i$ and $t$ variable indexes indicating for which country $i$ and which year $t$ the variable is considered. $Q$ is the volume of GDP, TFP the total factor productivity, $K$ the volume of capital installed at the end of the year, $N$ employment, i.e. the number of workers, and $H$ the average number of hours worked per year and per worker. $\alpha$ is the elasticity of output $Q$ to capital $K$ and, as in other studies (see for example Bergeaud et al., 2016a), we assume constant elasticity over time for all countries and the calibration: $\alpha=0.3$.

Total factor productivity takes into account the contribution of education to the quality of labor input through the average years of schooling in the working age population. This contribution is calibrated with a 5\% return on years of schooling, estimated in Bergeaud, Cette and Lecat (2016b) on the same database. This return lies within the range of estimates of "Macro-Mincer" equations such as Soto (2002), Cohen and Soto (2007) and Barro and Lee (2010).

This relation (1) can be written in growth rate terms:

(1') $\Delta q_{i, t}=\Delta t f p_{i, t}+\alpha \cdot \Delta k_{i, t-1}+(1-\alpha) \cdot\left(\Delta n_{i, t}+\Delta h_{i, t}\right)$

Or

(1'”) $\Delta q_{i, t}=\Delta t f p_{i, t}+\alpha \cdot\left(\Delta k_{i, t-1}-\Delta n_{i, t}-\Delta h_{i, t}\right)+\left(\Delta n_{i, t}+\Delta h_{i, t}\right)$

Where $x$ corresponds to the logarithm of the variable $X(x=\log (X))$, and $\Delta x$ is the usual approximation for the growth rate of $X .\left(k_{i, t-1}-\Delta n_{i, t}-\Delta h_{i, t}\right)$ is called capital intensity.

To build a future long-term scenario, for each country $i$, employment $N$ and working hours $H$ are exogenous. The quantification of volume of capital $K$ and of the TFP comes from specific assumptions and relations.

Concerning capital, we assume that in the long term, at the potential path, the capital coefficient (ratio of capital divided by GDP) remains constant in nominal terms (Cette, Kocoglu and Mairesse, 2005):

(2) $\Delta p q_{i, t}+\Delta q_{i, t}=\Delta p k_{i, t}+\Delta k_{i, t-1}$

Where $P_{Q}$ is the GDP price $\left(p q=\log \left(P_{Q}\right)\right)$ and $P_{K}$ the investment in the fixed productive capital price $\left(p k=\log \left(P_{K}\right)\right)$.

As in Cette, Kocoglu and Mairesse (2005), we observe in nominal terms over the last few decades in the US notable stability in the capital coefficient (Chart 1). The stability assumption thus seems reasonable. 
Chart 1

Capital coefficient, at current prices, in the US

(Ratio of capital stock to GDP in current prices)

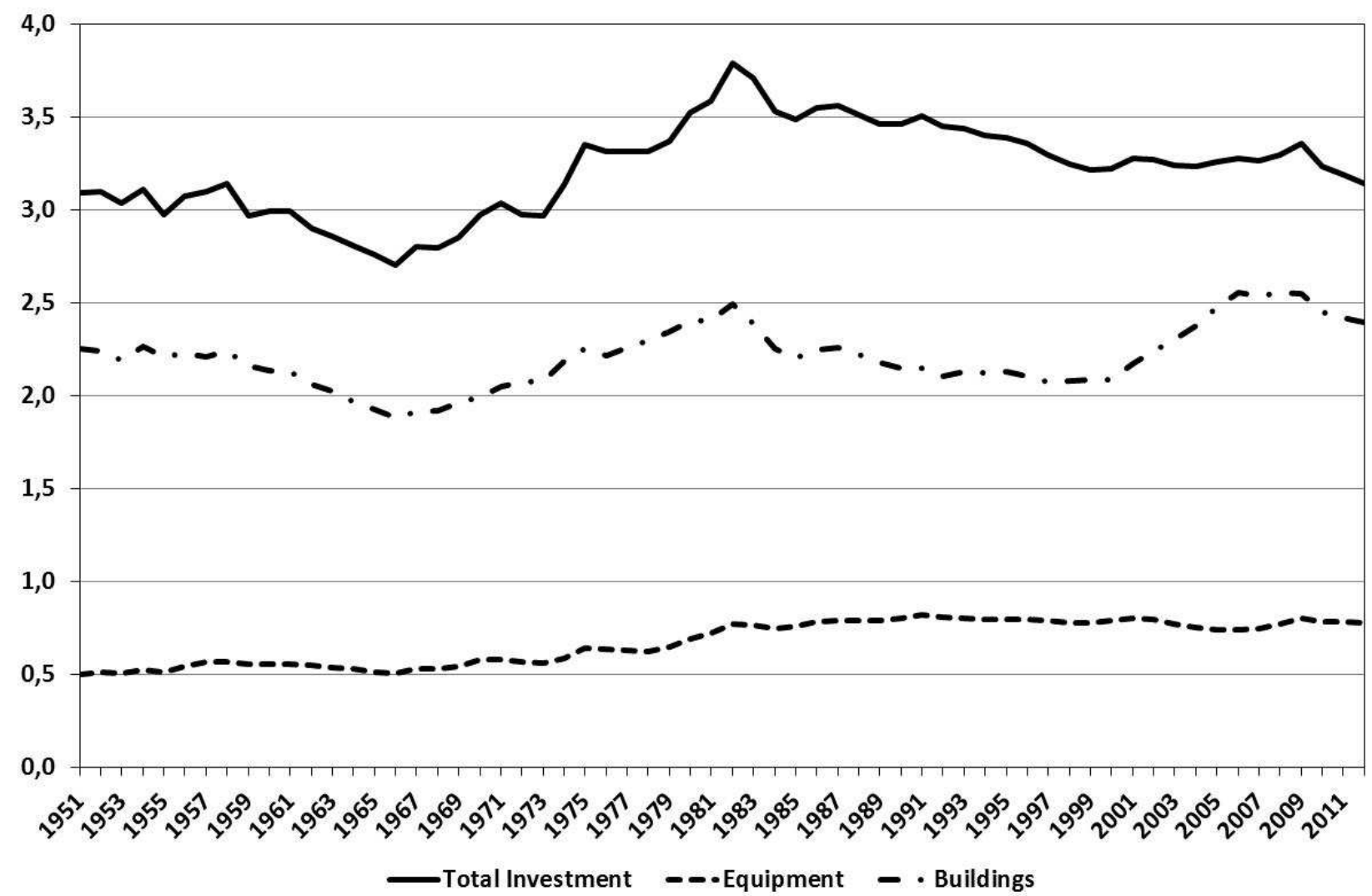

Source: Authors' calculation, see the data section.

From relation (2), we obtain the relation (2)', which is used to build long-term capital scenarios:

$$
\Delta k_{i, t-1}=\Delta p q_{i, t}+\Delta q_{i, t}-\Delta p k_{i, t}
$$

To build long-term capital evolution scenarios using relation (2'), we need a corresponding scenario of the relative investment price $(p k-p q)$ evolution. We assume that this relative price evolution depends, through an error correction model (ECM), on TFP evolution. The underlying theory is that, in the US, quality improvements in investment in terms of productive performance are at least partly incorporated into the measurement of investment prices in national accounts through hedonic or matching methods. This is mainly done for ICT since this investment benefits more than others from performance improvements (for a summary on these aspects, see Byrne, Oliner and Sichel, 2013, and Byrne, Fernald and Reinsdorf, 2016). So, the investment performance gains impact both investment prices and TFP. Taking all this into consideration, the relation estimated for the US is the following:

$$
\begin{aligned}
& \Delta p_{U S, t}=a_{0}+a_{1} \cdot \Delta p_{U S, t-1}+a_{2} \cdot \Delta t f p_{U S, t}+a_{3} \cdot \Delta t f p_{U S, t-1}+a_{4} \cdot\left(p_{U S, t-1}-\right. \\
& \left.a_{5} \cdot t f p_{U S, t-1}\right)+u_{t}
\end{aligned}
$$

Where $p_{U S, t}$ corresponds to the relative investment price in the US (in logarithm): 


$$
p_{U S, t}=p k_{U S, t}-p q_{U S, t}
$$

Increases in $t f p_{U S, t}$ lower the relative investment price $p_{U S, t}$ as the quality-adjusted price of investment decreases.

Relation (3) is estimated for the US. To build long-term relative investment price scenarios, we first build a long-term TFP scenario for the US and then use the estimated parameters of relation (3) to build the US relative price scenario. For the other countries $i$, we assume (as proposed by Schreyer, 2000, and numerous papers thereafter) that the relative price is the same as in the US:

$$
p_{i, t}=p_{U S, t}
$$

The long-term TFP scenarios are exogenous for the US. For the other countries $i$, we assume a catch-up process represented through an error correction model (ECM) in which intervene the level of education of the working age population ${ }^{6}$, regulation of the labor and product markets and, in the short run, changes in the capacity utilization rate, in the employment rate and in average working time. The following catch-up relation (5) is estimated:

(5) $\Delta t f p_{i, t}=\alpha_{1} \cdot\left[t f p_{U S, t-1}-t f p_{i, t-1}\right]+\alpha_{1} \cdot \alpha_{2} \cdot R_{i, t-1} \cdot\left[t f p_{U S, t-1}-t f p_{i, t-1}\right]+\alpha_{3} \cdot \Delta C U R_{i, t}+\alpha_{4} \cdot \Delta h_{i, t}+$ $\alpha_{5} . \Delta E R_{i, t}+\gamma_{i}+\delta_{t}+u_{i, t}$

Where $R$ is the level of anticompetitive regulation (product market x labor market regulation), $C U R$ the capacity utilization rate, ER the employment rate (here employment over population), and the $\gamma_{i}$ and $\delta_{t}$ country and year fixed effects.

In relation (5), the long-term TFP catch-up process to the US level depends on anticompetitive regulation on product and labor markets (more regulation lower the catch-up process, the expected sign of $\alpha_{2}$ being negative). In the short run, TFP growth also depends on changes in the capacity utilization rate of production factors (with a positive impact, the expected sign of $\alpha_{3}$ being positive) and on changes in the employment rate and hours (with a negative impact, the expected sign of $\alpha_{4}$ and $\alpha_{5}$ being negative). These three short term impacts are estimated in other studies (see Bourlès and Cette, 2007, or Aghion et al., 2009, for surveys and estimates). The employment rate and working hours have decreasing returns as less productive workers are recruited as the employment rate increases and because of tiredness effects with regard to working hours. Country and time dummies capture all the unobserved factors that may impact the convergence target: regulation that is not measured in our indicators (such as tariffs or banking regulations), the quality of management, corruption, etc. Year fixed effects capture the cycle common to all countries in our sample but also common movement in convergence targets across all these countries. It may appear, for example, that the ICT technology shock impacts the TFP level in the United States because of the share of ICT-producing industries in the US economy, which is lower in most countries of our sample, leading to a common downward shock in the convergence target for all non-US countries. We assume that the US remains the technology leader over the whole period and

6 Total factor productivity is adjusted for education, using the estimated return on years of schooling of 5\% from Bergeaud, Cette and Lecat (2016b): see equation (1'). The adjustment term for education, when extracted from $t f p$, is hence $-0.05 \times\left(E D U_{U S, t-1}-E D U_{i, t-1}\right)$ with $E D U$, the average years of schooling in the working-age population. 
that the convergence process continues as during our estimation period (1994-2010), which corresponds to the first ICT wave.

Relation (5) is estimated over our country panel. Non-US country TFP scenarios can be built using its estimated parameters and exogenous scenarios concerning US TFP.

\section{Data}

These models require the use of national accounts data (GDP, equipment and building investment, price of output and of investment in fixed productive capital, employment), of degrees of production factor utilization (capital utilization rates, hours worked per employee), population, education and regulation data.

For national accounts data $(G D P$, investment, employment, working hours, GDP and investment prices) and for education, population and production factor utilization data, we essentially use the dataset from Bergeaud et al. (2015, 2016a and 2016b) which gathers data for 13 OECD countries and the euro area over the period 1890-2013. These countries have been chosen for the large share of world GDP they represent: the G7 (the United States, Japan, Germany, France, the United Kingdom, Italy and Canada), four other euro area countries (Spain, the Netherlands, Belgium and Finland) and two other countries (Australia and Sweden). In addition, a euro area has been reconstituted, aggregating Germany, France, Italy, Spain, the Netherlands, Belgium, Portugal and Finland $(93.2 \%$ of the euro area GDP in 2010). A detailed description of the construction of this dataset is given in Bergeaud et al. (2016a and 2016b).

The capital indicator is constructed using the perpetual inventory method (PIM) applied to each of the two components (equipment $K_{E}$ and buildings $K_{B}$ ) with the corresponding investment data $\left(I_{E}\right.$ and $\left.I_{B}\right)$. The yearly depreciation rates used to build the capital series using the PIM are $10.0 \%$ for equipment and $2.5 \%$ for buildings following Cette et al. (2009) and are assumed to be constant across time and space. Finally, the damage that occurred during the World Wars, earthquakes in Japan and the civil war in Spain are, as much as available information will allow, taken into account in building the capital series. Chart 2 presents the yearly growth rate of capital intensity (the total capital stock over hours worked) over the estimation period; this displays a counter-cyclical pattern, as the capital stock tends to be more inert than hours worked. 
Chart 2

Capital intensity yearly growth rate $(\%)$

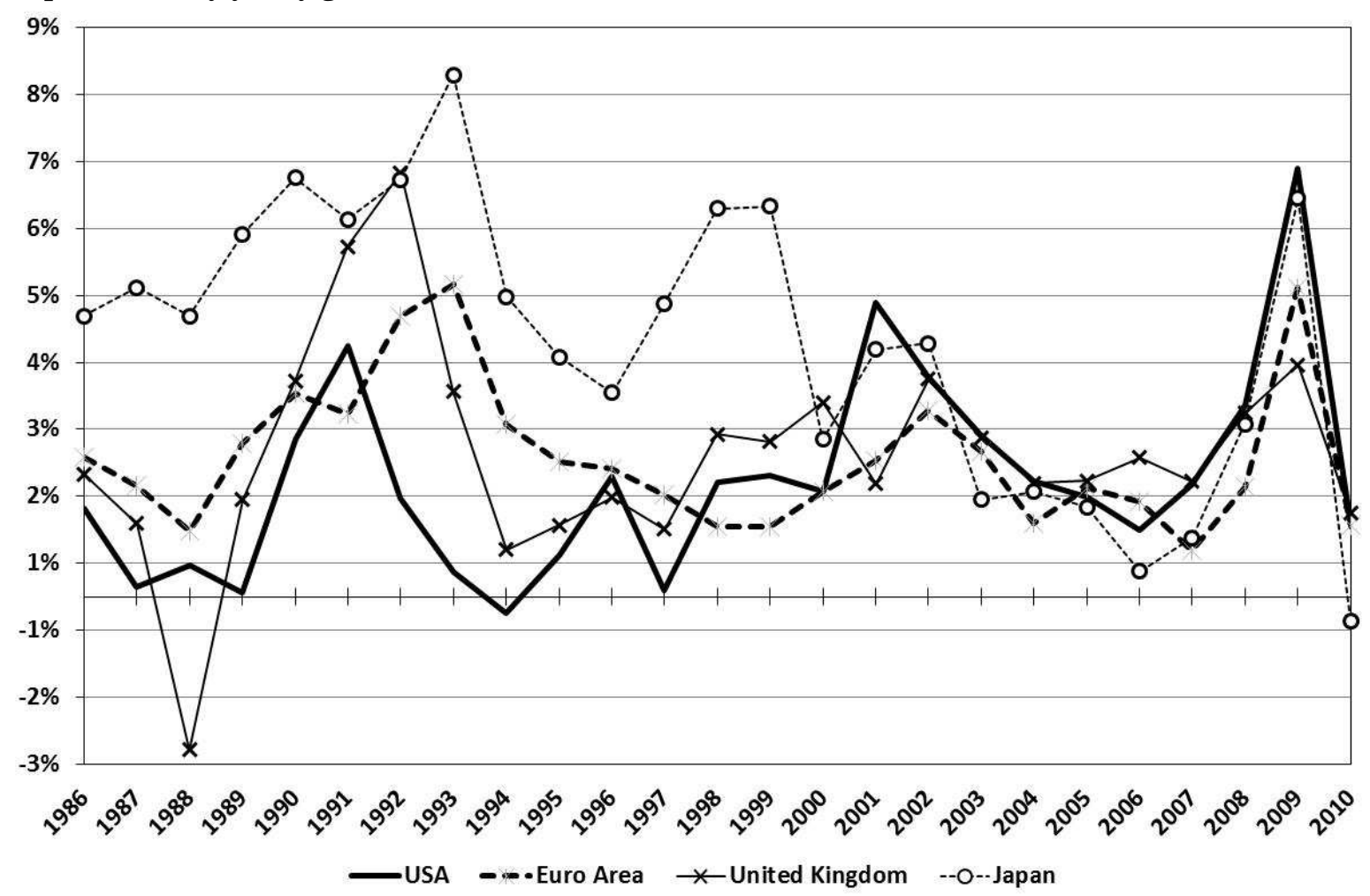

Source: Bergeaud et al. (2016b).

For education, we also use data collected by Bergeaud et al. (2016b). Educational attainment is defined by the average time spent studying in the total population over the age of 15 or $25^{7}$ using Van Leeuwen and Van Leeuwen-Li (2014). As shown in Chart 3, educational attainment rose continuously over the estimation period, with particularly large gains for the euro area and Japan.

The calculation starts with primary school and does not include kindergarten or any other type of education received before the age of 6 . 
Chart 3

Average years of schooling in the population aged over 15 (in years)

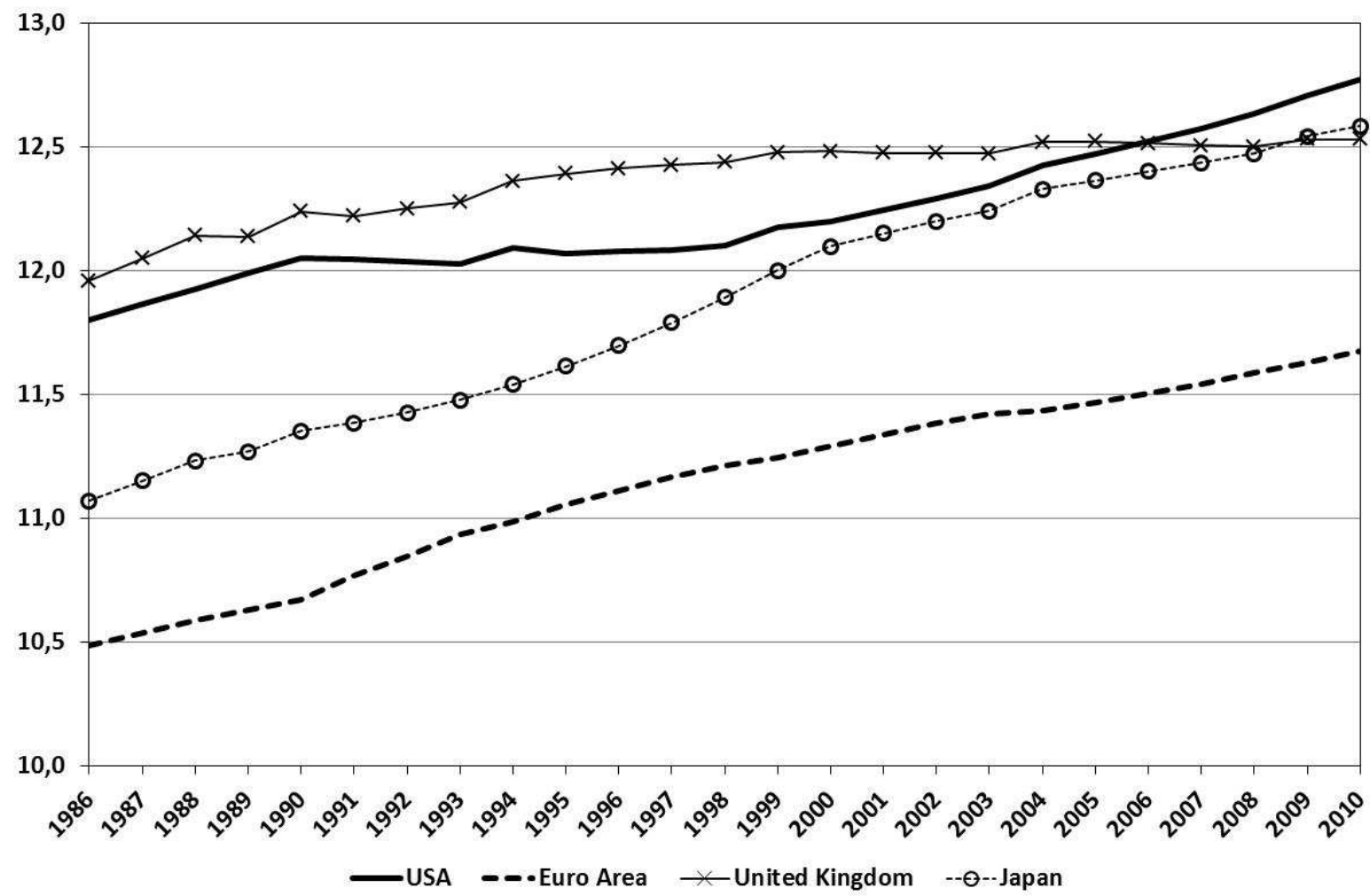

Source: Van Leeuwen and Van Leeuwen-Li (2014).

For population and employment rate projections up to 2060, we use those of the OECD (2015) and allow for parameterization afterwards. We therefore assume exogeneity of both these parameters, which may be endogenous to growth itself or regulation. Age structure could be a major determinant of long-term employment rate projections but is not concerned in cyclical developments. Lastly, the impact of regulation should be captured through our convergence equation.

We use OECD regulation indicators for employment protection legislation (EPL - OECD, 2013) and product market regulation (PMR - Koske et al., 2015). For employment protection legislation, we use permanent employment legislation as it is most representative of the stock of employment contracts. For product market regulation, we use the composite indicator encompassing state control, barriers to entrepreneurship and barriers to trade and investment. Both these indicators range between 0 (least regulated) and 6 (most regulated). Our regulatory indicator is the product of this EPL and PMR, assuming a non-linear relationship and a possible offsetting of one regulation by the other. ${ }^{8}$

\section{Capital stock dynamics}

Capital stock dynamics are assumed to depend on the stability of the capital stock to GDP ratio in nominal terms (see Section 2). Hence, to project the capital stock, we need to determine the trajectory of the relative investment price. As seen in equation (3), relative

If one body of regulation is at its maximum (6) and the other at the minimum (0), the overall regulation index will be 0 . In practice, both types of regulation tend to be correlated across countries. 
investment prices can be related to TFP through a dynamic error-correction model framework (ECM), as innovation tends to lead to decreasing investment prices, especially when quality adjustment is taken into account, compared to output prices. ${ }^{9}$ It is estimated on US data, not on a country-to-country basis, as US investment prices incorporate quality-adjusted information more efficiently than other countries, especially for recent periods.

Estimates are presented over different periods (from 1930 to 1990) in Table 1. We use the one-step estimate of the ECM, with the coefficients in first difference representing the shortterm relationship. Changes in relative investment price are fairly inert, as shown by the large and significant coefficient of $\Delta \ln \left(p_{t-1}\right)$ over all the periods. The short-term relationship with TFP is complex as the coefficient and the lagged coefficient are of opposite signs. In our preferred estimates (1970-2013), the overall coefficient of TFP is negative but small. The long-term relationship corresponds to the level variables $\left(\ln \left(p_{t-1}\right)\right.$ and $\left.\ln \left(t f p_{t-1}\right)\right)$, the coefficient for $\ln \left(p_{t-1}\right)$ being the error-correction term. It is negative in all of the columns, but is only significant for the 1970-2013 period. The coefficient of $\ln \left(t f p_{t-1}\right)$ is, from equation (3), the product of $a_{4}$, the error-correction term, and $a_{5}$, the long-term relationship between the relative investment price and total factor productivity. Hence, $a_{5}$ is significant and equals 0.73 , which implies that technological progress, as reflected by a $1 \%$ increase in TFP, will lead to a long-term decrease of 0.73 percentage point in relative investment prices. This estimate is consistent with Fisher's (2006) reaction function for investment-specific technology shocks. 1970-2013 is our preferred specification as the period is short enough to have a stable relationship among the variables ${ }^{10}$ and recent enough to have quality-adjusted data, but also because the period is long enough to estimate the coefficients precisely. Residual stability tests and cointegration tests are also more satisfactory on that period. ${ }^{11}$ Overall, the sign of the coefficients does not vary considerably from one estimate to the other but their significance and magnitude can display large variations. The results are robust to the exclusion of the crisis period from 2008 onwards.

9 The relationship between investment-specific technology shocks and the relative price of investment may be disrupted by several factors, such as mark-up changes or variation in the use of intermediate inputs and factors of production in technology-producing sectors (see Fisher, 2009). That is why we expect this relationship to hold more strongly in the long run than in the short run.

10 Benati (2014) shows over a long time horizon that relative investment prices and TFP are not cointegrated when structural breaks are not allowed; when introduced, long-horizon covariation is either nil or negative.

11 Cointegration is not rejected only for the regression from 1970 onwards (at the 5\% threshold), while it is rejected for all the other regressions (results are presented with a 20-year interval, but regressions at a 10-year interval were also tested). 
Table 1: Relative investment price estimates (equation (3)) on US data

\begin{tabular}{lcccc}
$\begin{array}{l}\text { Estimations for } \\
2013 \text { from... }\end{array}$ & 1930 & 1950 & 1970 & 1990 \\
& $\Delta \ln \left(p_{t}\right)$ & $\Delta \ln \left(p_{t}\right)$ & $\Delta \ln \left(p_{t}\right)$ & $\Delta \ln \left(p_{t}\right)$ \\
\hline$\Delta \ln \left(p_{t-1}\right)$ & $0.463^{* * * *}$ & $0.581^{* * * *}$ & $0.697^{* * * *}$ & $0.737^{* * * *}$ \\
& $(3.62)$ & $(5.57)$ & $(5.22)$ & $(6.28)$ \\
$\Delta \ln \left(t f p_{t}\right)$ & 0.0641 & -0.149 & $-0.268^{* *}$ & -0.267 \\
& $(0.61)$ & $(-1.41)$ & $(-2.09)$ & $(-1.69)$ \\
$\Delta \ln \left(t f p_{t-1}\right)$ & -0.0753 & 0.206 & 0.209 & $0.410^{* * *}$ \\
& $(-0.53)$ & $(1.66)$ & $(1.13)$ & $(2.89)$ \\
$\ln \left(p_{t-1}\right)$ & -0.0166 & -0.0211 & $-0.110^{* *}$ & -0.151 \\
& $(-0.84)$ & $(-0.81)$ & $(-2.15)$ & $(-1.52)$ \\
$\ln \left(t f p_{t-1}\right)$ & -0.00341 & -0.00873 & $-0.0803^{* *}$ & -0.0804 \\
& $(-0.34)$ & $(-0.57)$ & $(-2.12)$ & $(-1.12)$ \\
\hline$N$ & 84 & 64 & 44 & 24 \\
adj. $R^{2}$ & 0.172 & 0.402 & 0.546 & 0.680 \\
\hline
\end{tabular}

$t$ statistics in parentheses

" $p<0.1,{ }^{* *} p<0.05,{ }^{* * *} p<0.01,{ }^{* * *} p<0.001$

Notes: One-step error-correction model estimated on US data. First, we test the variables' integration order with two different unit root tests: the Augmented Dickey-Fuller (ADF) test and the PhillipsPerron (PP) test. As both time series are integrated of order 1, we model a cointegrated process and test its fitting results with Engle's Lagrange multiplier test, detecting for the presence of autoregressive conditional heteroskedasticity, and the Breusch-Godfrey and Durbin's alternative tests, both assessing for serial correlation in the disturbance and find that they are reliable from 1950 onwards (all tests available on request).

\section{Catch-up dynamics}

Although the TFP dynamics for the United States are exogenously determined by the technology scenario, the TFP dynamics for other countries are determined by a convergence process towards the technological frontier, defined as the US level. We thus estimate convergence equation (5), whose results are reported in Table 2. In Chart 4, we see that, for the euro area, Japan and the UK, catching up with the US level took place until the mid1990s, when the ICT shock led to a relative acceleration of US TFP. The euro area and the UK reached the US level, while others, such as Japan, remain far from it, which illustrates that countries may converge to different target TFP levels. 
Chart 4

Total factor productivity as a \% of the US level

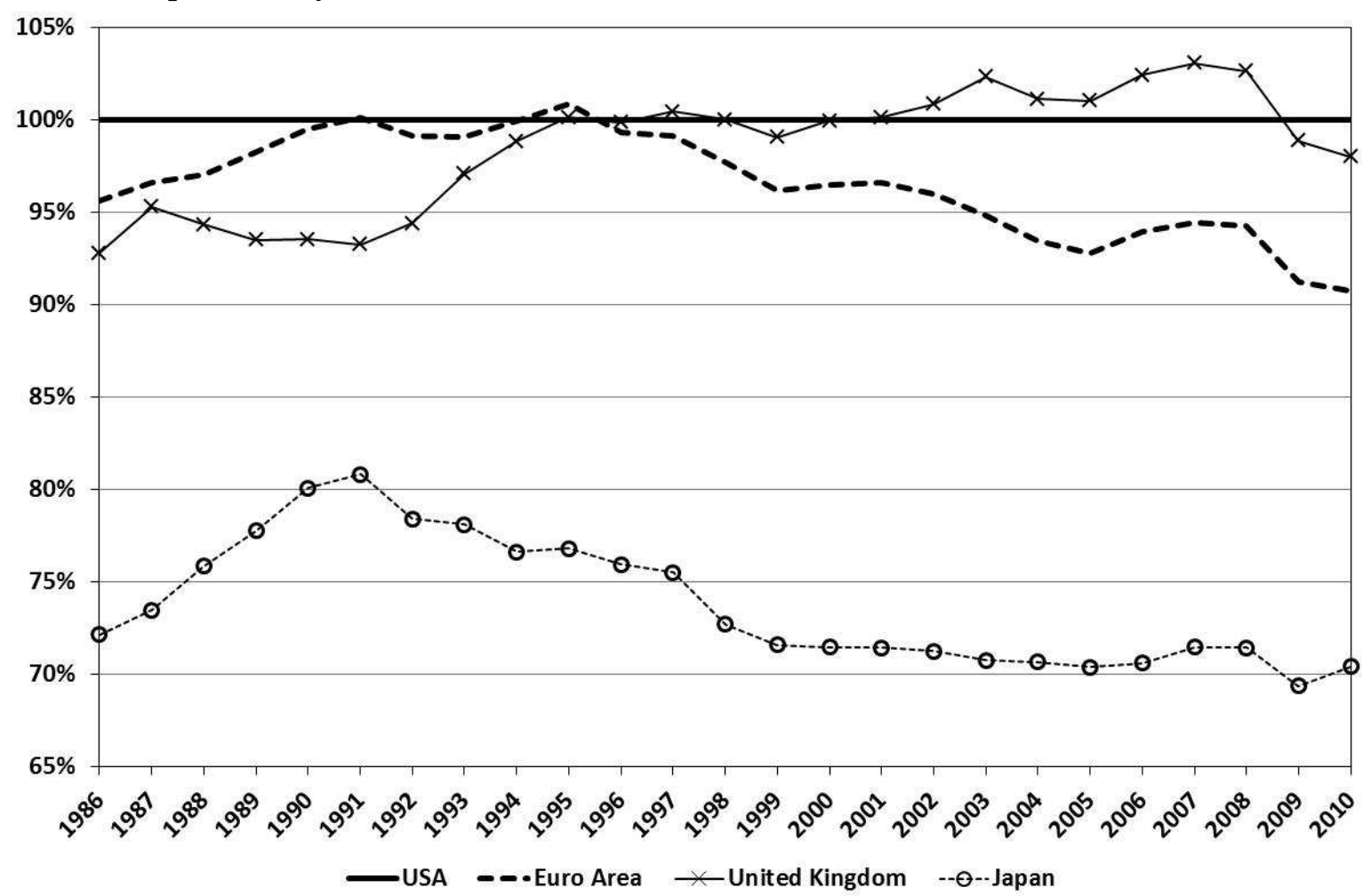

Source: Bergeaud et al. (2016b).

Our baseline specification includes convergence to the frontier, interaction of regulation and the frontier, all control variables, country fixed effects and year fixed effects from 1994 onwards. Other specifications include different periods, the regulation gap with the US rather than the level of regulation, different time periods, different returns on education and estimates without control variables.

Convergence to the frontier appears fast, especially in the period of the ICT technology shock that benefited the US more than most of the other countries in our panel: ignoring the interaction between the distance to the technological frontier and the level of regulation, about $14 \%$ of the gap is closed in one year for most specifications. However, this speed of convergence is reduced by the impact of labor and product regulation, whose average level is 7.35 over the sample. The coefficient of the interaction of regulation and the frontier is negative and significant, as expected. The speed of convergence is slower for countries with stringent labor and product regulations. Hence, the average speed of convergence is halved at the average regulation level, at $7 \%$ of the $T F P$ gap on average. ${ }^{12}$ Moreover, countries converge to different levels relative to the US, as estimates include country fixed effects and year fixed effects. Another specification choice could have been to introduce the level of regulation directly into the estimates so that the level as well as the speed of convergence depend on regulation. However, this is fully captured by our fixed effects, which encompass

12 As our specification is original, these results are not easily comparable with those in previous studies. Nevertheless, the sign and amplitude of the interaction term impact seem consistent with those in previous studies, which have also introduced interaction between the product of labor and product market regulation indicators and the distance to the TFP frontier indicator. See for example Aghion et al. (2009). 
all other unobservable factors not captured in our indicators (for example banking regulation). The use of the regulation gap with the US level does not alter our estimates of the impact of regulation, but it is not our preferred specification, as part of the impact of changes in US regulation should be captured in the US TFP level, which is included in the frontier variable.

Table 2: Catch-up estimates (equation (5))

\begin{tabular}{|c|c|c|c|c|c|c|}
\hline & $\begin{array}{c}\text { (1) } \\
\text { Baseline } \\
\Delta \ln \left(t / p_{1}\right)\end{array}$ & $\begin{array}{c}\text { (2) } \\
\text { Regulations gap } \\
\Delta \ln \left(t p_{0}\right)\end{array}$ & $\begin{array}{c}\text { (3) } \\
1986-2010 \\
\Delta \ln \left(t p_{*}\right)\end{array}$ & $\begin{array}{c}(4) \\
1990-2010 \\
\Delta \ln \left(t p_{p}\right)\end{array}$ & $\begin{array}{c}(5) \\
\text { Return on } \\
\text { education gap } \\
=7 \% \\
\Delta \ln (t p) \text {. }\end{array}$ & $\begin{array}{c}(6) \\
\begin{array}{c}\text { Without control } \\
\text { variables }\end{array} \\
\Delta \ln \left(t f_{s}\right)\end{array}$ \\
\hline Frontier & $\begin{array}{c}0.138^{\circ+1} \\
(3.87)\end{array}$ & $\begin{array}{c}0.139^{\cdots} \\
(4.00)\end{array}$ & $\begin{array}{c}0.0839^{*} \\
(3.31)\end{array}$ & $\begin{array}{c}0.102 \\
(3.46)\end{array}$ & $\begin{array}{c}0.140^{\circ} \\
(3.97)\end{array}$ & $\begin{array}{c}0.167 \\
(4.32)\end{array}$ \\
\hline Regulation - Frontier & $\begin{array}{c}-0.00920^{-} \\
(-2.54)\end{array}$ & & $\begin{array}{c}-0.00453^{*} \\
(-2.58)\end{array}$ & $\begin{array}{c}-0.00483^{*} \\
(-2.02)\end{array}$ & $\begin{array}{c}-0.00921 \cdots \\
(-2.91)\end{array}$ & $\begin{array}{c}-0.0111^{\cdots} \\
(-2.99)\end{array}$ \\
\hline $\begin{array}{l}\text { Regulation gap } \\
\text { Frontier }\end{array}$ & & $\begin{array}{c}-0.00980 \\
(-2.65)\end{array}$ & & & & \\
\hline$\triangle C U R$ & $\begin{array}{c}0.245 \\
(1.16)\end{array}$ & $\begin{array}{c}0.246^{\cdots} \\
(4.18)\end{array}$ & $\begin{array}{c}0.340^{\cdots+\cdots} \\
(7.94)\end{array}$ & $\begin{array}{c}0.314^{\cdots} \\
(7.25)\end{array}$ & $\begin{array}{c}0.244^{+\cdots} \\
(4.05)\end{array}$ & \\
\hline$\Delta \ln ($ hours) & $\begin{array}{l}-0.237^{*} \\
(-2.40)\end{array}$ & $\begin{array}{l}-0.238^{*} \\
(-2.41)\end{array}$ & $\begin{array}{c}-0.290^{\cdots} \\
(-3.19)\end{array}$ & $\begin{array}{c}-0.273^{\cdots} \\
(-3.00)\end{array}$ & $\begin{array}{l}-0.244^{*} \\
(-2.48)\end{array}$ & \\
\hline$\Delta$ Employment Rate & $\begin{array}{l}-0.255^{*} \\
(-2.02)\end{array}$ & $\begin{array}{l}-0.257+ \\
(-2.06)\end{array}$ & $\begin{array}{c}-0.0399 \\
(-0.31)\end{array}$ & $\begin{array}{l}0.0423 \\
(0.30)\end{array}$ & $\begin{array}{l}-0.265^{*} \\
(-2.07)\end{array}$ & \\
\hline Constant & $\begin{array}{c}0.0129^{* *} \\
(3.30)\end{array}$ & $\begin{array}{c}0.0130^{* *} \\
(3.31)\end{array}$ & $\begin{array}{c}0.0128^{\cdots \cdots} \\
(3.47)\end{array}$ & $\begin{array}{c}0.00967 \\
(1.51)\end{array}$ & $\begin{array}{c}0.0114^{\cdots} \\
(3.02)\end{array}$ & $\begin{array}{c}0.0167^{\cdots} \\
(3.48)\end{array}$ \\
\hline Observations & 192 & 192 & 288 & 252 & 192 & 192 \\
\hline Adjusted $R^{2}$ & 0.710 & 0.711 & 0.579 & 0.594 & 0.712 & 0.632 \\
\hline
\end{tabular}

Notes: 1994-2010 estimates apart from columns (3) and (4). Estimates include country and year fixed effects. Robust t-stats are reported.

The control variables yield the expected results. Capacity utilization rates capture the countryspecific cycle, which is not encompassed in the year dummies which capture the whole country sample cycle. Due to the imperfect measurement of factor utilization, which biases our TFP measure (Cette et al., 2015), this control is useful to correct for all cyclical effects. It is positive and significant in all specifications and its coefficient is fairly stable. The coefficients on the variations of hours worked per employee and of employment rates are negative, due to fatigue effects of longer hours and the recruitment of less productive workers as employment rates increase. The coefficients are negative, significant and stable across specifications, apart from the employment rate, which is not significant over 1986-2010 and 1990-2010. The magnitude of the coefficients is smaller than in Bourlès and Cette (2007), but their estimates are on productivity per employee and not $T F P .{ }^{13}$

Our preferred estimate is the 1994-2010 one (column (1)). It yields the highest $\mathrm{R}^{2}$ compared to other time periods, encompasses all control variables, uses a return on education more in line with literature and, as previously explained, the regulation gap leads to complex

13 And the employment rate corresponds here to the ratio of employment to population and not to the ratio of employment to working age population, as in Bourlès and Cette (2007). 
interpretations. Regulation measurement methodologies are also more robust and stabilized from the mid-1990s.

We may be concerned by a potential reverse causality between changes in TFP and regulation: in times of crisis, structural reforms may be easier. However, the literature on the political economy of structural reforms is not unanimous on this point; second, this reverse causality would bias our coefficient upward, which remains negative and significant; finally, regulations are lagged.

\section{Scenarios}

The outlook for productivity growth over the next few decades is subject to large uncertainties (6.1.). For this reason, very contrasting scenarios are built with our software (6.2.).

\subsection{Large uncertainties}

The future of productivity growth over the next few decades could differ at the technological frontier (the United States) compared to other developed countries. ${ }^{14}$ It depends dramatically on improvements in ICT -or other technologies- performance and on ICT diffusion. For this reason, the future of productivity growth is highly uncertain, and optimistic or pessimistic scenarios are both realistic. Gordon $(2012,2013,2014,2015)$, for example, is very skeptical about the extent of the current technology wave and argues that these contributions from ICT will be very small. According to him, labor productivity growth could stay on average close to $1 \frac{114 \%}{\%}$ per year, which corresponds to what was observed over the sub-period 1975-1995, from the first oil shock to the ICT productivity growth wave. Byrne, Oliner and Sichel (2013) propose two steady-state scenarios. In the first lower-bound one, the improvement in ICT performance, measured by ICT relative price growth, could remain on the same path as that observed on average during the 2004-2012 sub-period. It translates into a slowdown in ICT performance improvement compared with the 1995-2004 sub-period but also, in a slightly less pronounced way, compared with the 1974-1995 sub-period. But it also means an acceleration in comparison with what we observe in more recent years. In the second upperbound scenario, the improvement in ICT performance could follow an intermediate path relative to that observed in the 1974-1995 long sub-period and that observed in the favorable 1995-2004 sub-period. The contribution of ICT to future productivity growth (both from ICT capital deepening and from TFP in ICT producing sectors) differs between these two scenarios. It ranges from $1.8 \%$ to $2.5 \%$ for average annual labor productivity growth in the non-farm business sector. We could imagine more pessimistic scenarios than the lower-bound one (like what Gordon proposes) but also more optimistic scenarios than the upper-bound one.

A more optimistic scenario than the Byrne et al. (2013) upper-bound one could yield different results. The following ones are those primarily discussed in the literature: the first one stems from the fact that significant improvements could happen in the near future in the semiconductor industry (see ITRS, 2013a, 2013b). The next operational one could be the 3D chip; it will allow fast improvements in ICT performance for many years. This development

14 See Cette $(2014,2015)$ on these aspects. 
would increase the future contribution of ICT to productivity growth, which would engender a second ICT productivity growth wave benefiting the US. Secondly, large productivity gains could be generated by the extended use of available chips and ICT capacities in several new areas. This development was identified in 2005 by the ITRS as the 'More than Moore' process. Pratt (2015) gives some emphasis to the potential improvements in robotics and Mokyr et al. (2015) to the gains in research efficiency. It also justifies Brynjolfsson and McAfee's (2014) optimistic approach, which nonetheless stresses the need for appropriate institutions to reap the benefits from these potential gains. Rapid progress or even revolutions could take place in other domains, such as biotech, energy, agriculture... and fuel a "third technological revolution" scenario.

In the future, non-US advanced countries' productivity growth could also be positively influenced by a possible catch-up with the higher ICT diffusion level observed in the US. Numerous studies have suggested reasons for the gap in ICT diffusion in non-US advanced countries compared to the leading country, including the level of post-secondary education among the working age population as well as labor and product market rigidities. For example, efficient use of ICT requires a higher degree of skilled labor than the use of other technologies. The required firm reorganization for effective ICT adoption can be constrained by strict labor market regulations. Moreover, low levels of competitive pressure, resulting from product market regulation, can reduce the incentive to efficiently exploit production techniques. Numerous empirical analyses have confirmed the importance of these factors. ${ }^{15}$ Among others, Cette and Lopez (2012) show, through an econometric approach, that the US enjoys the highest level of ICT diffusion because of a higher level of post-secondary education among the working age population and less restrictive product and labor market regulations. This means that the future of productivity will depend, in all advanced countries, on technological progress, on the 'More than Moore process', but also on institutional changes through structural reforms to reap the full benefits from these advances. Concerning non-US countries, these institutional changes could potentially play a large role. Indeed, they would help to speed up the convergence to the US level of ICT productive capital diffusion.

\subsection{Two types of growth scenarios}

Two very different types of growth scenarios are proposed with the software (see Box for projection tool user manual) as to illustrate how much possible future outlooks differ. In the first one, named "Secular Stagnation", US TFP growth stays indefinitely at the low level observed both before (1974-1990) and after (2005-2014) the ICT productivity growth wave associated with the ICT third industrial revolution. In the second, called "technology shock", the US enjoys another large productivity growth wave associated with a third industrial revolution based on ICT or other technologies. The underlying TFP growth is then assumed to go back to the level observed during the 1990-2005 sub-period. We add to this trend growth a technology shock over four decades equivalent to the TFP contribution of electricity during the second industrial revolution in the $20^{\text {th }}$ century. For each of these two US growth scenarios, two sub-scenarios have been built concerning non-US countries. In the first one, education and regulation stay at their level at the beginning of the period, and TFP catch-up does not accelerate over the period. In the second, education and regulations converge to US levels over the 2015-2030 sub-period, which allows an acceleration of TFP convergence to

15 See Aghion et al. (2009), Guerrieri et al. (2011) and Cette and Lopez (2012), who use country-level panel data, as well as Cette, Lopez and Mairesse (2016), who employ sectoral-level panel data. 
the US level. For the UK, we did not include a specific treatment with regard to Brexit, as this shock is hard to calibrate, but it creates an additional downward risk on all the scenarios presented above.

\section{“Secular stagnation” scenarios}

In these scenarios, US TFP growth is stabilized at $0.6 \%$ per year, which corresponds to the level observed both before (1974-1990) and after (2005-2014) the ICT productivity growth wave associated with the ICT third industrial revolution, meaning that the US does not enjoy a new technology shock. We use OECD employment projections until 2060 and after that the contribution of employment stays around $0.5 \mathrm{pp}$ per year. The hours worked per worker decrease by $-0.1 \%$ per year, which corresponds to the evolution observed during the most recent historical sub-period 2005-2014. ${ }^{16}$ The average length of education stays stabilized at 12.8 years.

Under these assumptions, over the period 2015-2100, US GDP growth averages $1.5 \%$ (see Chart 5), with a contribution of $0.6 \mathrm{pp}$ from TFP, $0.5 \mathrm{pp}$ from capital intensity and $0.4 \mathrm{pp}$ from hours worked (itself decomposed in a contribution of $0.5 \mathrm{pp}$ from employment and $-0.1 \mathrm{pp}$ from hours worked per worker).

Chart 5

Average yearly GDP growth and contributions under the secular stagnation hypothesis

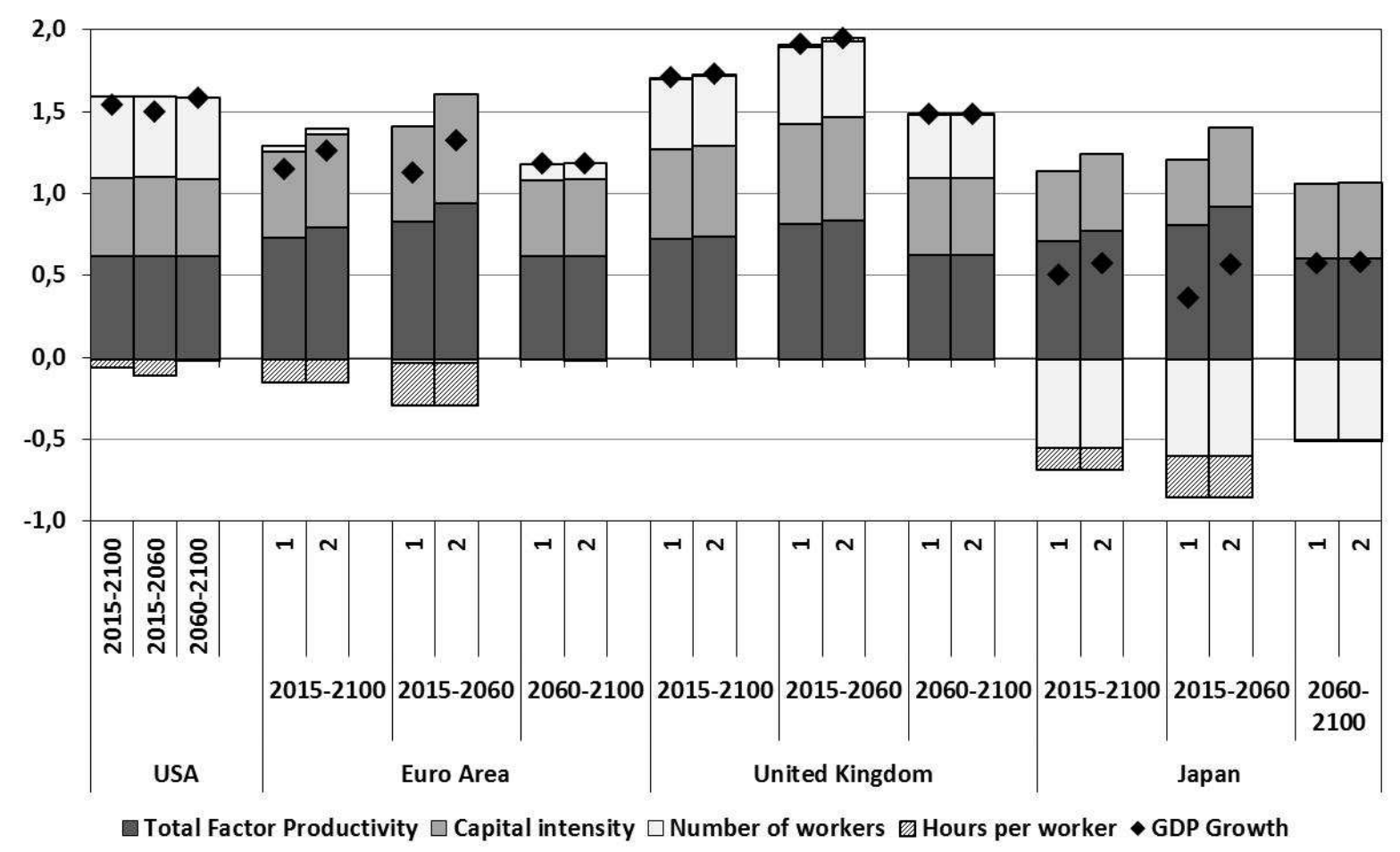

1: Without reforms and education convergence 2 : With reforms and education convergence

Source: Authors' computations.

Notes: this chart presents average yearly GDP growth under the secular stagnation hypothesis, with and without reforms (convergence of regulation and average years of education in the working-age population to the US level). GDP growth is decomposed into the contribution of $T F P$, capital intensity, the number of employees (labor) and hours worked per employee (hours), as presented in equation (1'”).

16 From 2060 onwards, hours worked per employee are stabilized. 
Concerning non-US countries, two scenarios are proposed. In the first one, without reforms, length of education and regulation remain stabilized at their 2014 levels. In the second, length of education and regulation converge to the US level (if their initial 2014 levels are above US ones, they remain stable) over the 2015-2035 sub-period. ${ }^{17}$ In both cases, hours worked per worker growth remain on their 2005-2014 trend until 2060, when they are stabilized, and employment growth corresponds to OECD projections.

These two growth scenarios differ slightly on average for non-US countries over the 20152100 sub-period as reforms act on the speed of convergence, which is low as a large share of the convergence to the target was achieved by 2015 for most advanced countries. Reforms speed up convergence for the lagging countries over the first period 2015-2060, with TFP gains higher by $0.2 \mathrm{pp}$ in the euro area and $0.1 \mathrm{pp}$ in Japan, but less in the UK. These higher TFP gains boost the contribution of capital intensity by $0.1 \mathrm{pp}$ in the three areas.

In both reform hypotheses, this secular stagnation scenario corresponds to low future GDP and productivity growth in developed countries. It means that the different headwinds identified by Gordon $(2012,1013)$ and mentioned in the introduction will be challenging to face. This scenario would be alarming, leading to risks of social and possibly political instability.

\section{“Technology shock” scenarios}

In the "technology shock" scenario, the US enjoys another large productivity growth wave mainly associated with the ICT third industrial revolution. This new wave could result from "More than Moore" advances (functional diversification of semiconductor-based devices) or upcoming positive technology shock (3D chips in particular) as emphasized by the International Technology Roadmap for Semiconductors (ITRS, 2013b). It could stem from advances in machine learning (Brynjolfsson and McAfee, 2014) or robotics (Pratt, 2015). It could also come from other domains such as biotech, energy, agriculture, etc. Mokyr et al. (2015) emphasize that technological progress is hard to predict, but that professionalization in R\&D activity, developments in new research tools and the overall increase in the number of world researchers support an optimistic view.

17 This reform effort is not exceptional: such an increase of the average length of education and such a decrease in the regulation index were observed in the 1990s and the 2000s in these countries. 
Chart 6

Average yearly GDP growth and contributions under the technology shock hypothesis

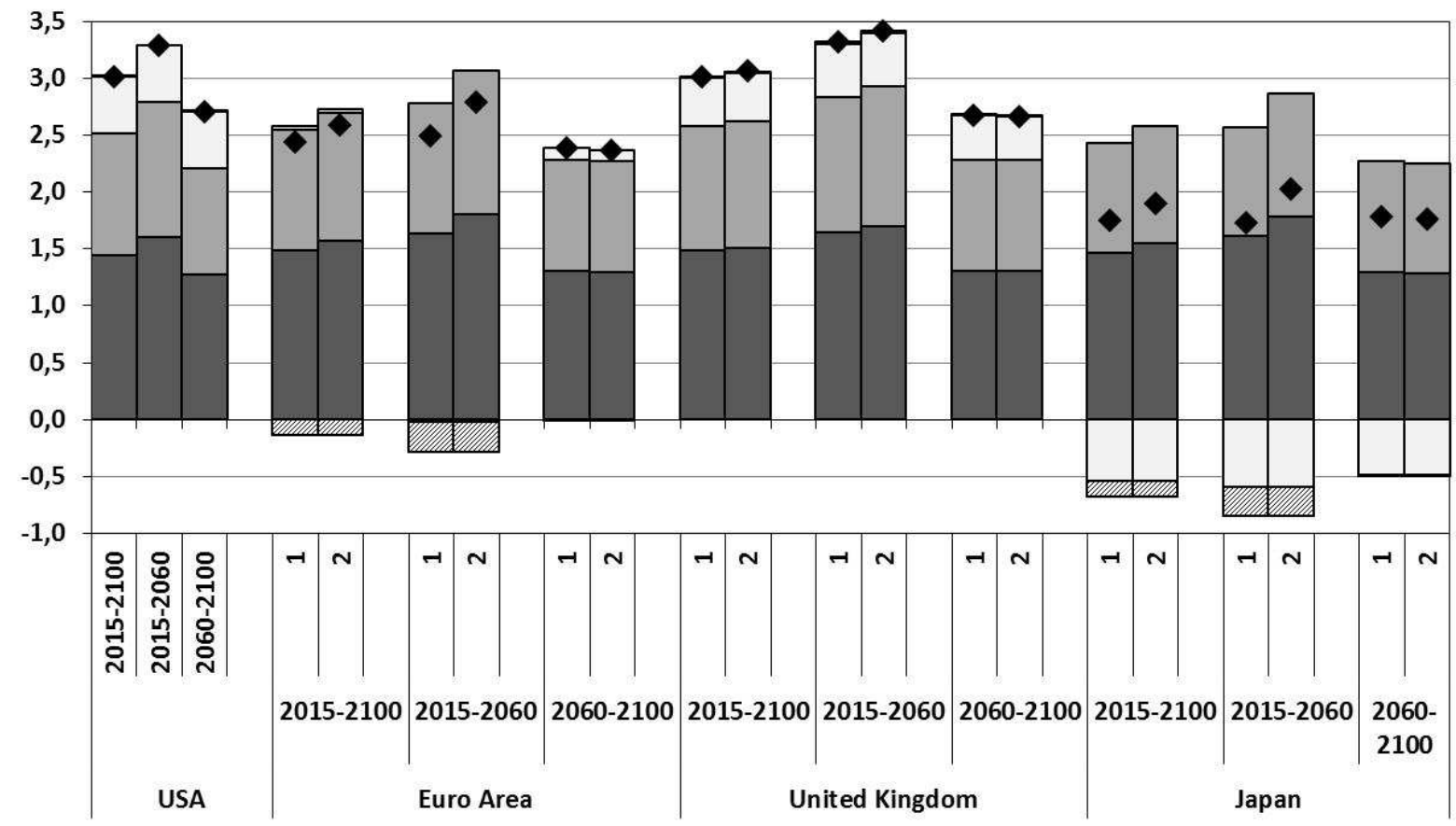

$\square$ Total Factor Productivity $\square$ Capital intensity $\square$ Number of workers $\square$ Hours per worker $\bullet$ GDP Growth

1 : Without reforms and education convergence 2 : With reforms and education convergence

Source: Authors' computations.

Notes: this chart presents average yearly GDP growth under the technology shock hypothesis, with and without reforms (convergence of regulation and average years of education in the working-age population to the US level). GDP growth is decomposed into the contribution of TFP, capital intensity, the number of employees (labor) and hours worked per employee (hours), as presented in equation (1',).

In this scenario, TFP growth is assumed to return to the pace observed during the 1990-2005 sub-period, from which we remove the contribution from the ICT technology shock ${ }^{18}$ in the US over that period (yielding a 1.3\% per year TFP trend, which is also the 1995-2014 average growth rate). This contribution is removed as a technology shock is added over this trend as a technology shock which is assumed to take place over four decades, with overall TFP gains associated with the ICT third industrial revolution equivalent to those observed for electricity during the second industrial revolution in the $20^{\text {th }}$ century, as estimated in Bergeaud, Cette and Lecat (2016b). The overall technology shock hence amounts to a $27 \%$ increase in TFP over these 40 years. ${ }^{19}$ Hours worked per employee are assumed to be stable. In this scenario, the US average annual GDP growth is $1.8 \mathrm{pp}$ higher than in the secular stagnation scenario during 2015-2060 and 1.2pp higher during 2060-2100.

In this scenario (see Chart 6), the yearly US GDP growth rate accelerates to $3 \%$ over the 2015-2100 period, with a $1.4 \mathrm{pp}$ contribution from $T F P, 1.1 \mathrm{pp}$ from capital intensity and $0.5 \mathrm{pp}$ from employment. Thus, the contributions from $T F P$ and capital intensity are more than double those in the secular stagnation scenario.

18 As estimated in Bergeaud, Cette and Lecat (2016b).

19 This figure corresponds to the overall gains from electricity, from which we remove the gains from ICT already accounted for up to 2015 . 
Here again, two sub-scenarios have been built for non-US countries. In the first one, education and regulation stay at their level at the beginning of the period, and the TFP catchup process takes place at its current pace. In the second, education and regulations converge to US levels over the 2015-2035 sub-period, which allows an acceleration of TFP convergence to the US level.

This acceleration takes place mostly during the 2015-2060 period, with the TFP contribution $0.2 \mathrm{pp}$ higher in the euro area and Japan, and the capital intensity contribution $0.2 \mathrm{pp}$ higher in the euro area and $0.1 \mathrm{pp}$ higher in Japan during this sub-period. The gains are more limited for the United Kingdom ( $0.1 \mathrm{pp}$ for $T F P$ ) as regulation levels are already close to US levels. Over the whole 2015-2100 period, the GDP growth rate would come out at a yearly average of $2.5 \%$ in the euro area, $3.0 \%$ in the United Kingdom and $1.9 \%$ in Japan. This pace would correspond to the 1974-1990 trend growth rate for the euro area, and the 1950-1974 rate for the United Kingdom, but would remain much lower than any $20^{\text {th }}$ century trend growth rate for Japan, as the overall contribution of labor would be negative.

In the first scenario (no change in education levels and no reforms), average annual GDP growth is higher than in the secular stagnation, during 2015-2060, by $1.3 \mathrm{pp}$ in the euro area, $1.1 \mathrm{pp}$ in the UK and 1.4pp in Japan. These gaps are 1.2pp in the euro area, 1.1pp in the UK and 1pp in Japan during 2060-2100.

In these technology shock scenarios, there is no doubt that the different headwinds set out by Gordon $(2012,1013)$ and mentioned in the introduction would be easy to face, in the US and also in non-US countries, if there were a convergence of education and regulation to US levels.

\section{Box: \\ The projection tool: a user-friendly software}

The software is a user-friendly projection tool that allows the user to compute different growth scenarios for 13 developed countries based on inputted parameters concerning the technological frontier's growth path and the follower countries' convergence process. This software is freely available at www.longtermproductivity.com.

In an Excel format, the file contains 16 sheets that can be separated into 3 categories:

- The hypothesis sheet where parameters are entered concerning the projections for each country with regard to TFP and the follower countries' convergence, relative prices, average hours worked per year and per worker, employment, labor and product market regulation, and education.

- The individual countries' sheets where the user can observe visual output of his inputted parameters in the hypothesis sheet (GDP annual growth rate, TFP annual growth rate and level, capital annual growth rate, total employment growth rate, average hours worked per year and per worker annual growth rate, relative price annual growth rate, annual product and labor market regulation indexes, and annual level of education in years).

- The TFP sheet recapitulating all of the countries' TFP growth rates in data format and charts.

To program a long-term growth scenario, the user has to input assumptions into the hypothesis page.

The user is first invited to enter his assumptions about the technological frontier, the United States, with regard to TFP, relative capital prices, average hours worked per year and per worker, education 
and employment.

For the leading country, the user can implement (or not) a technology shock and control for its magnitude and duration, in addition to a TFP trend. There are four parameters: the trend's yearly growth rate, the wave length in years, its peak year, and its height over the trend.

For the trend's yearly growth rate, the user can either choose to directly input a percentage by clicking on 'manual entry', or he can compute a past trend by clicking on 'past trend' and enter into the input box a start year and an end year. If the user simulates a technology shock, he inputs its duration in years in the box labelled 'wave length', in which year it reaches its peak and by what percentage in the boxes labelled respectively 'wave peak year' and 'wave peak height over trend'. If the user does not wish to have a technology shock, he simply inputs $0 \%$ in the 'wave peak height over the trend' box.

For the relative capital price, the user can either choose to manually enter a yearly growth rate, which can be directly inputted or computed on a past trend, or choose the paper's modelized trend.

Concerning average hours worked per year per worker, the user is asked to enter three parameters: the yearly growth rate, the target number of hours and its catch-up start date. For the yearly growth rate, the user can either enter it manually or compute a past trend in addition to a minimum and a maximum number of hours worked per year per worker. If the user wishes to make assumptions about working hours legislation, he can input a target number of hours that the country will converge towards starting from the year inputted in 'catch-up start date'. If not, he simply manually inputs $0 \%$ in the 'yearly growth rate' and the country's previous number of hours in the 'target number of hours', which is indicated in the adjacent box.

The user can also make assumptions about the average length of education by entering a target education level in years and the date at which the country starts converging towards it. If not, he simply inputs the previous education level in the 'target education level' (displayed in the adjacent box).

Finally, the user is asked to make assumptions about the employment rate from 2060 (when the OECD's projections end). He can either input a manual entry or compute a past trend.

The user can now make assumptions about the follower countries' convergence process to the technological frontier. All countries have the same parameters related to assumptions about TFP, relative capital price, average hours worked per year and per worker, education, market regulation, and employment.

For TFP, the user can either choose to manually enter the country's catch-up parameters or he can choose the paper's modelized trend. If he chooses the 'manual entry', he will control the trend's yearly growth rate (manual entry or past trend), the date at which the country starts converging to the leader's targeted TFP level, the targeted TFP level, and the speed of convergence.

The relative capital price can either be manually entered, by actually inputting a yearly growth rate or computing a past trend, or can follow the paper's modelized trend.

Average hours worked per year per worker are set through three parameters: the yearly growth rate, the target number of hours and its catch-up start date.

For the yearly growth rate, the user can either make a manual entry or compute a past trend in addition to a minimum and a maximum number of hours worked per year per worker.

If the user wishes to make assumptions about working hours legislation, he can input a target number of hours to which the country will converge, starting at the 'catch-up start date'. If not, he simply 
manually inputs $0 \%$ in the 'yearly growth rate' and the country's previous number of hours in the 'target number of hours', which is indicated in the adjacent box.

The level of education may converge to the United States' targeted education level if the user enters a catch-up start date, a convergence speed, and a target level. If he does not wish the country's education level to vary, he simply enters $0 \%$ in the 'converging speed'.

The user can implement up to two market regulation reforms on both the labor market and the product market. To do so, he first clicks on 'regulations 1' and enters the catch-up start and end year into the new inputted index. For a second reform the step is repeated. If the user does not wish to introduce market reforms, he simply re-enters the country's previous index (indicated in the output box).

Finally, the user is asked to make assumptions about the employment rate from 2060 (when the OECD's projections end). He can either input a manual entry or compute a past trend.

At the end of the hypothesis sheet, in the parameters section, the user can see an ON/OFF switch for the HP function. We advise you to only turn it $\mathrm{ON}$ once you have entered all the assumptions as the Hodrick-Prescott filter is rather time consuming when computing data.

\section{Concluding remarks}

The analyses proposed in this paper illustrate how future growth in advanced countries is driven by technology improvements at the technological frontier (the US) and the catch-up process to this frontier in terms of productivity in other countries. However, their respective paces are very uncertain in the future. In the US, it depends on new technological changes, in particular in the ICT industry, and on the extension of the use of available ICT capacities in several areas (the 'more than Moore' process). In other countries, it also depends on the institutional economic environment and on the capacity to implement large-scale and ambitious structural reforms.

The user-friendly software presented in the paper was used to build different scenarios illustrating these uncertainties at a very long horizon, from the current period to 2100, the end of the century. These scenarios are deliberately extremely contrasting, and show how wide the range of possible future growth is for the developed countries. In the lower scenario, improvements in purchasing power and living standards would be very small, making it challenging to face the 'headwinds' talked about by Gordon $(2012,2013)$. Social and political stability could be seriously threatened in such a low growth scenario. By contrast, in the upper scenario, gains in purchasing power and living standards would be great, and Gordon's 'headwinds' would be easily overcome.

There is no consensus in the literature on the future of growth drivers and, for this reason, it seems difficult to attribute probabilities to these diverse scenarios. We assume the that the future growth of developed countries will probably settle between the extreme scenarios described in the paper, but the literature is not yet very conclusive in helping identify exactly where. But the software can be used to build more precise scenarios for those who have a specific opinion on what may happen regarding growth drivers over the next decades.

This software is of course based on a set of hypotheses and simplifications. It does not yet allow for the introduction of different demographic scenarios nor for explicit account to be taken of the issue of environmentally sustainable growth. It is the first step in a long research 
program, the next two steps being the inclusion of both of these aspects. Bearing this in mind, it is still a practical tool that enables us to represent different possible growth paths, and to characterize the associated issues in developed countries. 


\section{References}

Aghion, P., P. Askenazy, R. Bourlès, G. Cette and N. Dromel (2009): "Education, Market Rigidities and Growth", Economics Letters 102 (1), pp. 62-65.

Benati, L. (2014): "Do TFP and the relative price of investment share a common I(1) component?", Journal of Economic Dynamics and Control, vol. 45, August, pp. 239-261.

Bergeaud, A., G. Cette and R. Lecat (2015): "GDP per capita in advanced countries over the $20^{\text {th }}$ century", Working papers No. 549, Banque de France.

Bergeaud, A., G. Cette and R. Lecat (2016a): "Productivity trends from 1890 to 2012 in advanced countries", The Review of Income and Wealth, vol. 62, issue 3, pp. 420-444.

Bergeaud, A., G. Cette and R. Lecat (2016b): "The role of production factor quality and technology diffusion in 20th century productivity growth", Working Papers No. 588, Banque de France, forthcoming in Cliometrica.

Barro, R. and J. Lee (2010): "A new data set of educational attainment in the world, 19502010”, NBER, Working Papers No. 15902, National Bureau of Economic Research, Inc.

Bourlès, R. and G. Cette (2007): "Trends in "structural" productivity levels in the major industrialized countries," Economics Letters, Elsevier, vol. 95(1), pages 151-156, April.

Brynjolfsson, E. and A. Mcaffee (2014): "The second machine age - Work, progress, and prosperity in a time of brilliant technologies", Kindle edition.

Byrne, D., J. Fernald and M. Reinsdorf (2016): "Does the United States have a Productivity Slowdown or a Measurement Problem?” NBER, Working Papers Series No. 2016-3, March.

Byrne, D., M. Oliner and D. Sichel (2013): "Is the information technology revolution over?", International Productivity Monitor, No. 25, Spring, pp. 20-36.

Cette, G. (2014): "Does ICT remain a powerful engine of growth", AFSE Presidential Address, Revue d'Economie Politique, 124 (4), July-August, pp. 473-492.

Cette, G. (2015): "Which role for ICTs as a productivity driver over the last years and the next future?", Digiworld Economic Journal, Communications \& Strategies, No. 100, $4^{\text {th }}$ quarter, pp. 65-83.

Cette, G., N. Dromel, R. Lecat and A.-C. Paret (2015): "Production Factor Returns: The Role of Factor Utilization," The Review of Economics and Statistics, MIT Press, vol. 97(1), pp. 134-143, March.

Cette, G., Y. Kocoglu and J. Mairesse (2005): "ICT and potential output growth", Economics Letters, vol. 87, Issue 2, pp. 231-234.

Cette, G., Y. Kocoglu and J. Mairesse (2009): "Productivity growth and levels in France, Japan, the United Kingdom and the United States in the Twentieth Century," NBER Working Papers, No. 15577. 
Cette, G. and J. Lopez (2012): "ICT demand behaviour: an international comparison", Economics of Innovation and New Technology, Taylor and Francis Journals, vol. 21(4), June, pp. 397-410.

Cette, G., J. Lopez and J. Mairesse (2016): "Upstream product market regulations, ICT, R\&D and productivity", forthcoming in The Review of Income and Wealth.

Cohen, D. and M. Soto (2007): "Growth and Human Capital: Good Data, Good Results", Journal of Economic Growth, 12(1):51-76.

Crafts, N. and K. O'Rourke (2013): “Twentieth Century Growth", Discussion Paper Series, CEPR, No. 9633, September.

Duval, R. and C. de la Maisonneuve (2010): "Long-run growth scenarios for the world economy”, Journal of Policy Modeling, Elsevier, vol. 32(1), pp. 64-80, January.

Eichengreen, B. (2015): "Secular Stagnation: The Long View", American Economic Review, Papers \& Proceedings, 105(5), pp. 66-70.

Fisher, J. (2006): “The Dynamic Effects of Neutral and Investment-Specific Technology Shocks," Journal of Political Economy, 114, pp. 413-451.

Fisher, J. (2009): "Comment on Letting Different Views about Business Cycles Compete", NBER Chapters, 24, 457-474.

Fouré, J., A. Benassy-Queré and L. Fontagné (2013): "Modelling the world economy at the 2050 horizon", Economics of Transition, Wiley-Blackwell, 21(4), pp. 617-654.

Gordon, R.J. (2012): "Is U.S. Economic Growth Over? Faltering Innovation Confronts the Six Headwinds", NBER, Working Papers 18315, National Bureau of Economic Research, Inc.

Gordon, R.J. (2013): "US Productivity Growth: The Slowdown Has Returned after a Temporary Revival", International Productivity Monitor, Centre for the Study of Living Standards, vol. 25, Spring, pp. 13-19.

Gordon, R.J. (2014): “The Demise of U.S. Economic Growth: Restatement, Rebuttal, and Reflections." NBER, Working Papers 19895, February.

Gordon, R.J. (2015): "Secular Stagnation: A Supply-Side View", American Economic review, Papers \& Proceedings, 105(5), pp. 54-59.

Guerrieri, P., M. Luciani and V. Meliciani (2011): "The determinants of investment in information and communication technologies." Economics of Innovation and New Technology 20 (4), pp. 387-403.

Hansen, A. (1939): "Economic Progress and Declining Population Growth", American Economic Review, vol. 29, No.1, pp. 1-39. 
ITRS (2013a): “International Technology Roadmap for Semiconductors”, 2012 edition update.

ITRS (2013b): "International Technology Roadmap for Semiconductors”, 2013 edition.

Jorgenson, D. (2001): "Information technology and the US economy", The American Economic Review, vol. 91, March, No. 1.

OECD (2013): "Protecting jobs, enhancing flexibility: A new look at employment protection legislation", Chapter 2 of the 2013 Edition of the OECD Employment Outlook.

Koske, I., I.Wanner, R. Bitetti and O. Barbiero (2015): "The 2013 update of the OECD product market regulation indicators: policy insights for OECD and non-OECD countries", OECD Economics Department Working Papers, 1200/2015.

Maddison, A. (2001): “The World Economy: A Millennium Perspective," Development Centre Studies, Development Centre of the Organization for Economic Co-operation and Development.

Mokyr, J., C. Vickers and N. L. Ziebarth (2015): "The history of technological anxiety and the future of economic growth: Is this time different?", Journal of Economic Perspective, vol. 29, No. 3, Summer, pp. 31-50.

Pratt, G. A. (2015): "Is a Cambrian explosion coming from robotics?", Journal of Economic Perspective, vol. 29, No. 3, Summer, pp. 51-60.

Schreyer, P. (2000): "The Contribution of Information and Communication Technology to Output Growth: A Study on the G7 Countries", OECD Science, Technology and Industry Working Papers 2000/2, OECD.

Soto, M. (2002): "Rediscovering Education in Growth Regressions", OECD Development Centre Working Papers 202, OECD Publishing.

Summers, L. (2014): "U.S. Economic Prospects: Secular Stagnation, Hysteresis, and the Zero Lower Bound", Business Economics, vol. 49, No. 2, pp. 65-74.

Summers, L. (2015): “Demand Side Secular stagnation”, American Economic Review, Papers \& Proceedings, 105(5), pp. 60-65.

Van Leeuwen, B. and J. van Leeuwen-Li (2014): "Education since 1820", In: J.L. van Zanden et al. (eds.), "How Was Life?: Global Well-Being since 1820", OECD Publishing, pp. 88-101. 


\section{Documents de Travail}

600. M. Mogliani and T. Ferrière, "Rationality of announcements, business cycle asymmetry, and predictability of revisions. The case of French GDP” September 2016

601. R. S.J. Koijen; F. Koulischer; B. Nguyen and M. Yogo, "Quantitative Easing in the Euro Area: The Dynamics of Risk Exposures and the Impact on Asset Prices" September 2016

602. O. de Bandt and M. Chahad, “A DGSE Model to Assess the Post-Crisis Regulation of Universal Banks” September 2016

603. C. Malgouyres, "The Impact of Chinese Import Competition on the Local Structure of Employment and Wages: Evidence from France" September 2016

604. G. Cette, J. Lopez and J. Mairesse, "Labour market regulations and capital labour substitution” October 2016

605. C. Hémet and C. Malgouyres, "Diversity and Employment Prospects: Neighbors Matter!” October 2016

606. M. Ben Salem and B. Castelletti-Font, "Which combination of fiscal and external imbalances to determine the longrun dynamics of sovereign bond yields?" November 2016

607. M. Joëts, V. Mignon and T. Razafindrabe, "Does the volatility of commodity prices reflect macroeconomic uncertainty?" November 2016

608. M. Bussière, G. Gaulier and W. Steingress, "Global Trade Flows: Revisiting the Exchange Rate Elasticities" November 2016

609. V.Coudert and J. Idier, “An Early Warning System for Macro-prudential Policy in France” November 2016

610. S. Guilloux-Nefussi, “Globalization, Market Structure and Inflation Dynamics” December 2016

611. S.Fries, J-S. Mésonnier, S. Mouabbi, and J-P. Renne, "National natural rates of interest and the single monetary policy in the Euro Area" December 2016

612. J. Blaum, C. Lelarge and M. Peters, “The Gains from Input Trade with Heterogeneous Importers” December 2016

613. A. Penalver, “Optimal Monitoring of Long-Term Loan Contracts” December 2016

614. M. Isoré and U. Szczerbowicz, "Disaster Risk and Preference Shifts in a New Keynesian Model” December 2016

615. L. Chauvet and L. Jacolin, "Financial Inclusion, Bank Concentration and Firm Performance” December 2016

616. P. A. Pintus, Y. Wen, and X. Xing, "The Inverted Leading Indicator Property and Redistribution Effect of the Interest Rate" December 2016

617. G. Cette, R. Lecat \& C. Ly-Marin, "Long-term growth and productivity projections in advanced countries" December 2016

Pour accéder à la liste complète des Documents de Travail publiés par la Banque de France veuillez consulter le site : www.banque-france.fr

For a complete list of Working Papers published by the Banque de France, please visit the website:

www.banque-france.fr

Pour tous commentaires ou demandes sur les Documents de Travail, contacter la bibliothèque de la Direction Générale des Études et des Relations Internationales à l'adresse suivante :

For any comment or enquiries on the Working Papers, contact the library of the Directorate General Economics and International Relations at the following address :

BANQUE DE FRANCE

49- 1404 Labolog

75049 Paris Cedex 01

tél : 0033 (0)1 42977724 ou 0142926340 ou 4890 ou 6981

email : 1404-ut@banque-france.fr 